\title{
THE EVOLUTION OF EDUCATIONAL MARKETING *
}

\author{
Natalia MANEA ${ }^{1}$, Mihaela PURCARU ${ }^{2}$ \\ ${ }^{1}$ University Politehnica of Bucharest, 313, Spl. Independentei, Bucharest, \\ 060042, Romania, Tel.: +40723087095, Email: natalia.manea@upb.ro \\ ${ }^{2}$ Bucharest University of Economic Studies, Romana Square no 6, Bucharest, \\ 010374, Romania, Tel.: +40728209258, Email: mihaela.purcaru@mk.ase.ro
}

\begin{abstract}
The association of the term 'educational' to the term 'marketing' generates a specialized domain, by applying methods, politics and marketing strategies in the area of education. Due to the cultural, social and complex role of the education, educational marketing represents a part of the services marketing, the social marketing and the non-profit organizations. By offering mandatory educational services, financed from the state budget, the school units, through their activity, respect the principles of social marketing, regardless of the financial benefits that result from the provision of these services.

This article aims to place educational marketing below the conceptual level in the field of service marketing; the reference works in the field of educational marketing are not many, a consequence of the fact that this is a new field.
\end{abstract}

Keywords: educational pillars; educational marketing; social marketing; services marketing.

JEL Classification: $\mathrm{M}_{31}, \mathrm{I}_{23}$

\section{Introduction}

Education is a human oriented activity, mean to develop the human personality, thus determining the development of the society. Firstly, education occurs inside the family, afterwards takes a new shape inside the school units, inside the church. The mass-media's influence is not to be avoided neither - though

${ }^{*}$ This article was presented at ICESBA 2017 (International Scientific Conference on Economic Sciences and Business Administration), Intercontinental Hotel, Bucharest, 24-25 of November 2017. 


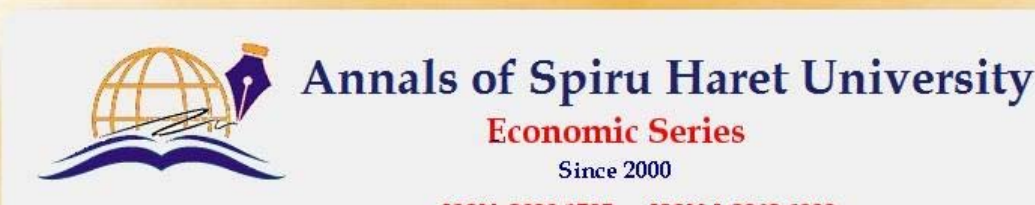

ISSN: 2393-1795 ISSN-L:2068-6900

Issue 4/2017

it cannot be controlled by the human being, it has a very strong impact. Learning inside the educational units is a systematic activity, managed with the objective to gain as much knowledge, aptitudes, personality shaping competences as possible.

\section{Literature review}

The most important and relevant contribution in the literature, in my opinion, is related to Gyönös' paper written in 2011, which is emphasizing the purpose of the educational marketing: maximize the effects of an educational process and bring into harmony the individual interests together with the collective ones, when it comes to learning. Thus, by a larger definition of education, this presumes the process that develops the capacities, ideas and human behaviours.

\section{Educational marketing - conceptual determinations}

In 1985, Strategic Marketing for Educational Institutions by Philip Kotler and Karen F.A. Fox appeared and offered solid marketing foundations for the basic activities of the school units. In 1993, the work of John H. Holcomb came to surface, named Educational Marketing, referring to the public schools systems in America. His work offers methods for more efficient educational services by improving the activities of the pupils, the members of the administrative council, the school directors, etc. Andrew Hockley, in his book entitled Educational Management, tackled subjects related to the organizational culture, the human resources, the consumer's behaviour, the financial management and also the projects' management in the school units.

In Romania, in 1976, M. C. Demetrescu's article called "Social Marketing for Education" appeared in Magazine of Pedagogy. Among the most important papers in Romanian language, we can name the ones belonging to the university professors Gabriel Brătucu and Ana Ispas, „Introduction into the Social Marketing”, respecttively „Social Marketing”.

At the beginning of 1990, a study has been conducted showing that the educational marketing was interpreted in a very narrow context of the communications marketing definition. This study had as a standpoint a hypothesis supporting the idea that in order to ensure the success of the market universities, there is a great need for the managers to examine the process of decision taking and also to examine the way it is perceived by the potential student. At the same time, it was concluded that any student can be considered also a client for the educational product. [Manea, 2015] 


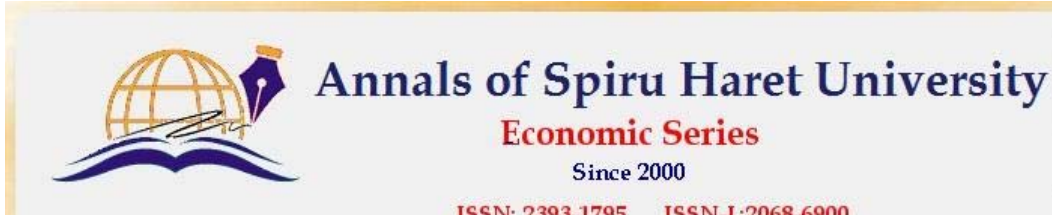

ISSN: 2393-1795 ISSN-I-2068-6900

Issue 4/2017

Just two decades after the first debates on introducing the marketing topic into the educational management practice, the adepts of the educational marketing have strongly claimed that education can be 'marketed' in a social, ethical and educationally responsible way [Stachowski, 2011], so that the educational marketing term has become a formal one, being introduced in the second half of 1980 in the United States of America and Great Britain, moment marked by the launching of some publications, such as 'how to promote your school', that were based on marketing models that were previously developed in the lucrative sector. The emergence of the marketing term into the university management lexicon is also framed by Maringe and Mourat (2012) at the beginning of 1980.

Oplatka and Hemsley-Brown are substantiating that the educational marketing represents an indispensable management function that is vital for the educational units in the competitive environment nowadays, as the efficiency of an educational unit itself is not enough and it has to illustrate an efficient image among parents and stakeholders, as well. In addition to that, the adoption of the marketing practice in the superior educational units represents a solution to decrease the negative effects of educational services extension, on a general level, which manifests more and more as a lack of individualized attention among the students, a crucial problem of the university management in the context of global competition. [Petruzzellis \& Romanazzi, 2010]

Stachowski (2011) completes the series of arguments in favour of adopting the educational marketing by inventorying its benefits:

- better accomplishment of the institutions' missions;

- increased satisfaction of employees and pupils;

- the ability to attract more resources, financial and non-financial;

- increased efficiency of the marketing actions, in general.

\section{Educational marketing, component of the services marketing}

In the context of the definition, the service can be defined by facts, processes and the performance to be composed of all those actions and reactions that the consumers have understood to purchase [Agrawal, 2001]. In a larger definition, the services represent any act or performance that can be offered to any other party, an act that is essential and intangible and does not lead to obtaining the property right over anything; the production of that act can be or cannot be related to a physical product [Enasel, 2012]. Referring to the essence of services, those are defined by economical activities that create value and offer benefits to the consumers in 


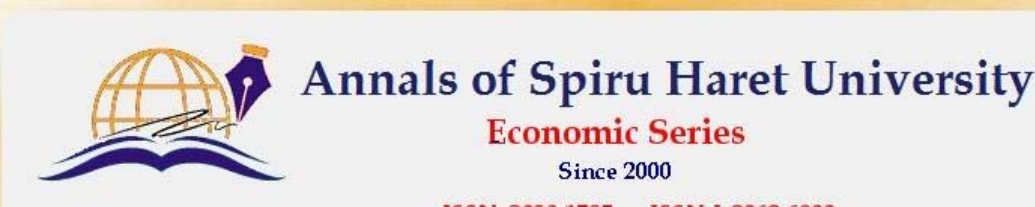

ISSN: 2393-1795 ISSN-L:2068-6900

Issue 4/2017

certain moments, specific places, as a result of the action to generate the desired change in the name of the one that receives the service [Lovelock \& Wright, 1999].

From all the range of definitions encountered in the major literature, the most representatives for the different stages of the conceptualization of services marketing are considered to be the ones made by the Marketing American Association (1960), Leonard L. Berry (1980) and Philip Kotler (1986).

According to the American Association, the services represent activities, benefits or utilities that are offered on the market or performed in close relation to the sale of a good. The definition given by L.L. Berry proves to be particularly concise and it tells that the service is an activity, an effort, a performance. According to the definition provided by P. Kotler, the service represents any activity or advantage that can be offered to the other and that, in essence, has an intangible character, not having as a result the property right of one thing over the other. Most of the definitions encountered in the specialty literature are emphasising the fact that services are 'activities that have a result that is not material and cannot be stocked', they do not apply to products that have an independent existence. [Enache, 2003]

\section{Educational marketing, component of social marketing}

The main goal of social marketing is to develop constructive approaches that support the desired behavioural changes and underpin the principle of increasing public perception that the benefits of new behaviour exceed the costs of adopting that behaviour [Kotler \& Lee, 2009]. The social marketing concept has its roots in the rhetorical question from 1951, of the American academician Wiebe: "Why can't we sell our brotherhood in the same way as we are selling the soap?", an idea that found productive grounds in Kotler's paper work from 1969 that was sustaining that marketing is a social activity, universally spread, which goes beyond the spectrum of toothpaste, soap or iron sale [Kotler \& Levy, 1969].

These first steps are the basis for introducing the official term of "social marketing" by Kotler and Zaltman, when, through their pioneer work, they formed the basis for demonstrating the use of marketing for analyzing, planning and controlling the issues of social change. The argument that stands as a pillar for embracing the concept of philosophy and marketing tools for social causes derives from the marketing discipline that provides the context for the development of new solutions to the social problems we face and which most often amaze and frustrate the society [Lefebvre, 2013].

At bottom, social marketing stands on two main pillars: firstly, it focuses on people, their needs and demands, aspirations, lifestyle and freedom of choice and 40 


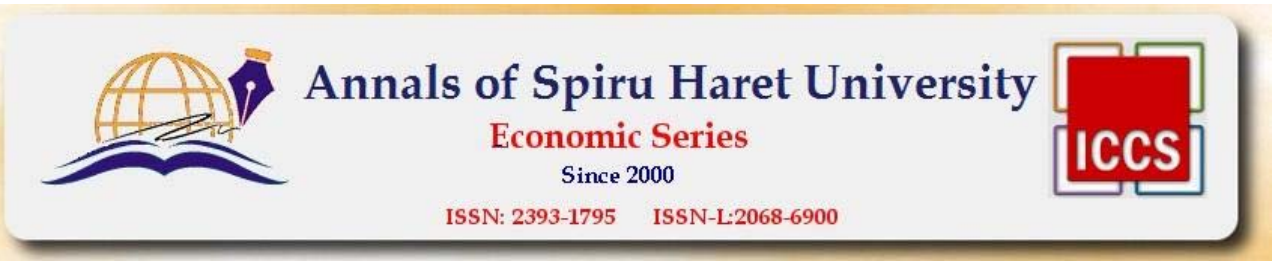

Issue 4/2017

secondly, social marketing has as main objective the change of the involved behaviour, the target of all social marketing projects being the segments of the priority population and not the people [Lefebvre, 2011] and it is a systematic process of managing the strategic allocation of resources to address widespread social problems [Lefebvre, 2013].

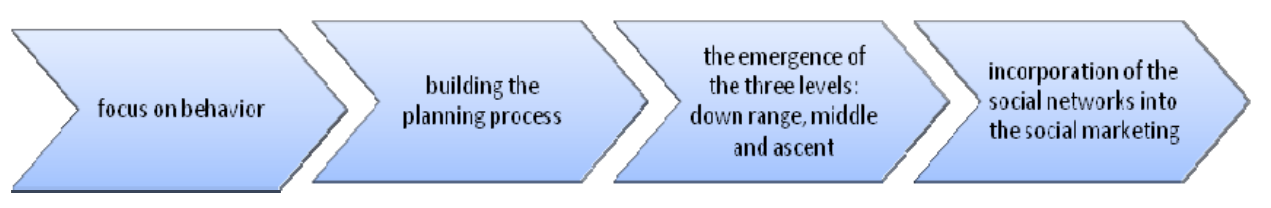

Figure no. 1. Evolution of the social marketing concept

Source: Adaptation of the Dibb \& Carrigan's classification (2013)

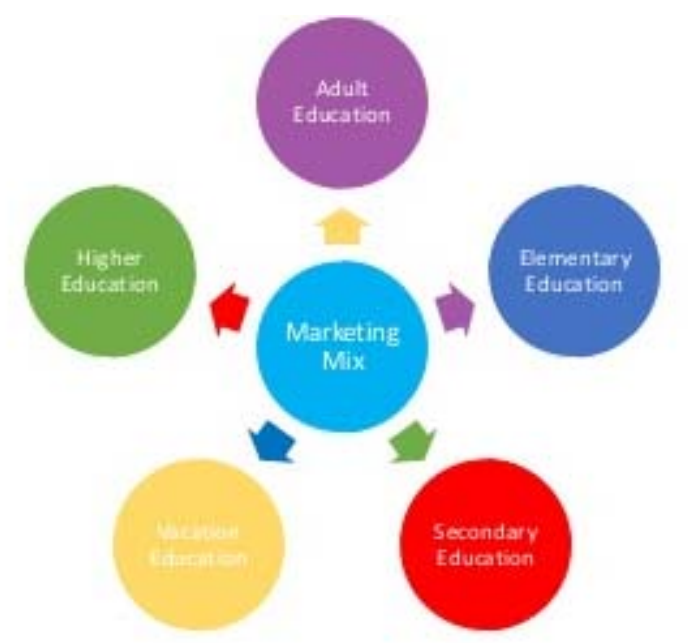

Figure no. 2. Educational marketing mix

Source: Kondwani B.J. Manda (2014)

According to a more recent definition, the social marketing is a process that applies the principles and techniques of marketing to create communication and deliver value, in order to influence the audience target behaviour for the benefits of 


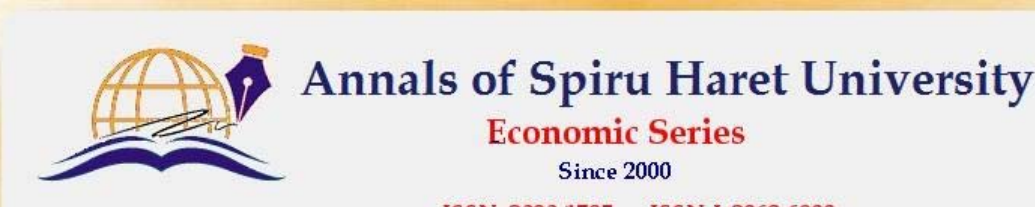

ISSN: 2393-1795 ISSN-L:2068-6900

Issue 4/2017

the society (public health, safety, environment, community), as well as the respective target audience [Kotler \& Lee, 2009]. From a more practical point of view, the social marketing defines an organized effort led by a group with the intention to convince the others to accept, change or give up some ideas, attitudes, practices and behaviours [Cihovska, 2013]. Being a field enriched with challenges and opportunities, the social marketing has become, in the last years, an instrument to change the largely recognized behaviour that is used by non-profit organizations and governments for the social welfare promotion. [Pang \& Kubacki, 2015]

On the other side, the evaluation of affiliation to the lucrative or non-lucrative services sector, in parallel with the evaluation of affiliation to the public sector vs the private sector, a series of shades need to be highlighted: the mandatory education (in the case of our country, until the high school) enters under the sphere of the non-lucrative services from the public sector (excepting the alternative private system that have a lucrative purpose, but have in the same time an area of coverage very narrowed, especially in the big urban centers).

\section{Educational marketing: a strategy for building customer loyalty}

Educating customers about products and services has long been a priority for leading companies. But new Internet-based approaches now enable them to develop far deeper customer relationships through ongoing education and information sharing. You can too, by applying our five critical success factors, your marketing challenge.

Advanced communication technologies now make it possible for companies to interact directly with their clients, distributors, channel partners and other important stakeholders in ways never dreamed possible until quite recently. Leading companies are maximizing those opportunities with a variety of approaches to support their business objectives. Instead of focusing solely on product-related information, they pursue communication and learn strategies that emphasize flexibility, interactivity and understanding, with a fundamental focus on enabling customer success. Educational content is often packaged for consumption via the Internet or mobile devices to win the favour of busy clients who are deluged with information.

A properly developed and executed educational marketing initiative is the antithesis of a hard-sell marketing campaign. It is a highly professional educational program dedicated to keeping valued clients informed about important issues and trends related to their interests. Its sole purpose is to help customers achieve success with their objectives and pursuits, not to push products and services. 


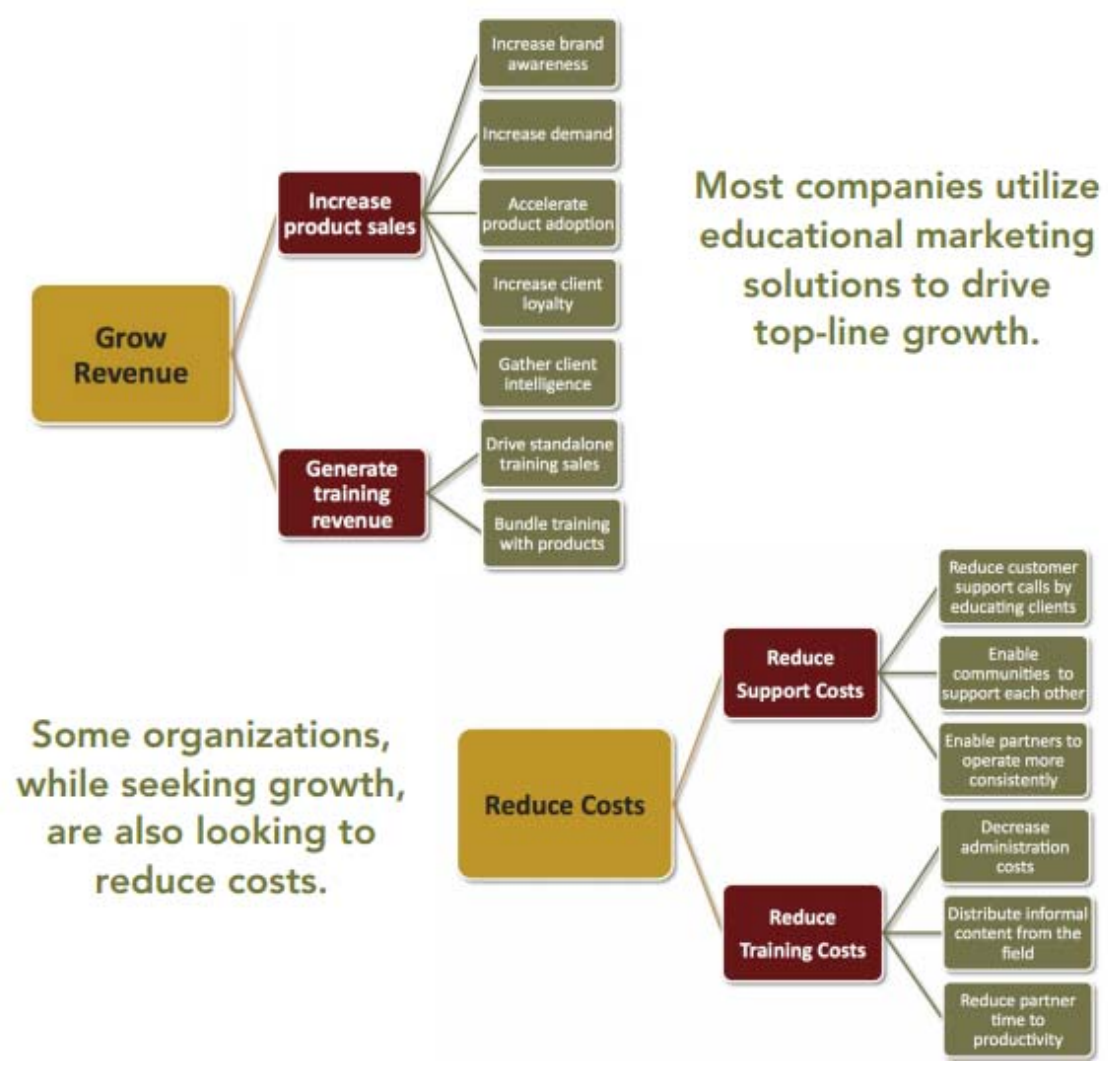

Figure no. 3. Educational marketing framework - mapping goals and drivers Source: Intrepid Learning Solutions Report, 2010

\section{Conclusions}

Educational marketing represents the extension of marketing's application in the education sector, approached by school units to differentiate themselves on the education market and to develop long-term relationships with all stakeholders, from all categories. This marketing orientation has as main argument the fact that the higher education passes through an era of change, a statement that gives the impression that is part of the TINA syndrome (,There-Is-No-Alternative"), maybe even an era of radical changes [Stensaker \& D'Andrea, 2007]. Therefore, in the face of the environmental challenges, the paradigm of higher education needs to be 


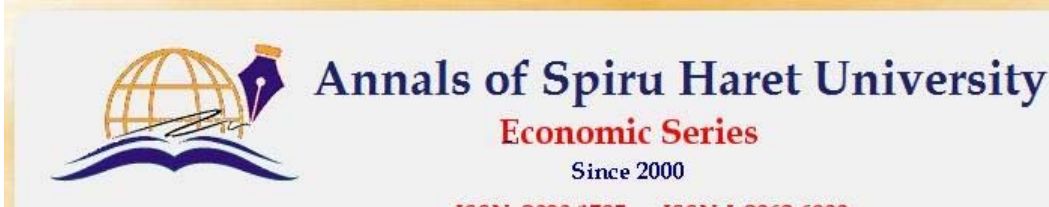

ISSN: 2393-1795 ISSN-L:2068-6900

Issue 4/2017

continually restructured from the grounds in order to facilitate the entrepreneurial spirit and needs a coordinated strategy that focuses on the consumer [Judson et al., 2009].

Taking into account the numerous defining characteristics of the approached sectors until now in this chapter, a series of conclusions regarding the context of educational marketing can be enunciated. On the one hand, given the intangible nature of the purpose of the educational act (except for a diploma that is, in fact, a way to certify that the educational objectives related to knowledge, skills and abilities have been met), the involvement of the "client" in the provision of the service (educational objectives that can only be achieved with the help of contact persons for the achievement of educational objectives) can prove that educational marketing is an area of the large service marketing sector.

In the business perspective, we have an effective educational marketing that applies best practices of adult learning theory to ensure customer engagement and success. At the same time, educational marketing achieves measurable business objectives to satisfy the most skeptical directors looking for clear and measurable results. It builds trust, loyalty and credibility with customers, which directly translates to increased customer retention and higher revenues. Educational marketing programs that are well executed also cut through the din of today's incessant drumbeat of low-value, high-volume marketing "noise," and credibly position companies with the coveted status of "trusted advisor."

\section{References}

1. Agrawal, M.L., "Building a New Academic Field in India: The Case of Services Marketing," Journal of Service Research 1(1), (2001): 104-20.

2. Cihovska, V., "Social Orientation of Marketing Concept," Journal of Positive Management (2013): 52-62.

3. Donovan, R. \& Henley, N., Principles and Practice of Social Marketing: An International Perspective (Cambridge: Cambridge University Press, 2010).

4. Enache, I.-C., "Marketing Higher Education Using the 7Ps Framework," Bulletin of the Transylvania University of Braşov 4(53), (2011): 23-30.

5. Enasel, I.-O., "The Customer-Employee Relationship in Services Marketing" (paper published in the Proceedings of the International Conference Marketing - from Information to Decision, $5^{\text {th }}$ edition, Risoprint, Cluj-Napoca, 2012).

6. Gyönös, E., "Early School Leaving: Reasons and Consequences," Theoretical and Applied Economics, Volume XVIII, No. 11(564), (2011): 43-52 
7. International Bank for Reconstruction and Development, World Development Report 2018 - Learning to Realize Education's Promise, http://www.worldbank.org/en/ publication/wdr2018/brief/world-development-report-2018-data.

8. Judson, K.M., Aurand, T.W., Gorchels, L. \& Gordon, G.L., "Building a University Brand from Within: University Administrators' Perspectives of Branding," Service Marketing Quarterly 30(1), (2009): 54-68.

9. Kotler, P. \& Lee, N.R., Up and Out of Poverty: The Social Marketing Solution (New Jersey: Wharton School Publishing, 2009).

10. Lefebvre, R.C., Social Marketing and Social Change: Strategies and Tools for Health, Well-Being, and the Environment (San Francisco: Jossey-Bass, a Wiley Imprint, 2013).

11. Lovelock, C.H. \& Wright, L., Principles of Service Marketing and Management, 1st ed. (New Jersey: Prentice Hall, 1999).

12. Manea, N., Marketingul serviciilor educaționale, abordare din perspectiva universitară (București: Printech, 2015).

13. Maringe, F. \& Gibbs, P., Marketing Higher Education: Theory and Practice (New York: Open University Press, McGraw-Hill Education, 2009).

14. Maringe, F. \& Mourad, M., "Marketing for Higher Education in Developing Countries: Emphases and Omissions," Journal of Marketing for Higher Education, volume 22, no. 1 (2012): 1-9.

15. Oplatka, I. \& Hemsley-Brown, J., "Research on School Marketing, Current Issues and Future Directions, An Updated Version," in I. Oplatka \& J. Hemsley-Brown, eds. Management and Leadership of Educational Marketing: Research, Practice and Applications (Advances in Educational Administration, Volume 15, Emerald Group Publishing Limited, 2012), 3-35.

16. Orîndaru, A., "Developing Marketing Higher Education Strategies Based on Students' Satisfaction Evolution in Time" (paper presented at the $15^{\text {th }}$ Eurasia Business and Economics Society Conference, Lisboan, 8-10 January 2015, and published in the Romanian Economic Journal, Vol. XVIII, no. 57, 2016), 167-182.

17. Pang, B. \& Kubacki, K., "The Four Es of Social Marketing: Ethicality, Expensiveness, Exaggeration and Effectiveness," Journal of Social Marketing 5(1), (2015): 83-99.

18. Plantz, M.C., "Salient Hopes and Fears: Social Marketing to Promote Human Services," Community Mental Health Journal 16(4), (1980): 293-305.

19. Stachowski, C.A., "Educational Marketing: A Review and Implications for Supporting Practice in Tertiary Education," Educational Management Administration \& Leadership 39(2), (2011): 186-204.

20. Stensaker, B. \& D'Andrea, V., Branding - The Why, What and How Phenomenon (Amsterdam: The European, 2007). 
